\title{
X-linked intellectual disability, Siderius type
}

INSERM

\section{Source}

INSERM. (1999). Orphanet: an online rare disease and orphan drug data base. X-linked intellectual disability, Siderius type. ORPHA:85287

X-linked intellectual disability, Siderius type is characterised by mild to borderline intellectual deficit associated with cleft lip/palate. Preaxial polydactyly, large hands and cryptorchidism are sometimes present. The syndrome has been described in seven boys from two families. Transmission is X-linked and the syndrome is caused by mutations in the PHF8 gene, localised to the p11.21 region of the X chromosome. 